under his order of Peritrichous Infusoria *, in which it forms the true ordinal type, the "nucleus and central point" to which the other groups approximate upwards and downwards.

We have treated the systematic history of the Vorticellan family in more detail perhaps than the following observations may render necessary; but the history of the classification of a group of animals is always the true expression of the development of the knowledge of it; and in the present case it is of the greater interest, because it shows in how rare a fashion the Vorticellina have shown themselves to be a coherent and closed group, as, in spite of all efforts at further development, the systematic combination has remained essentially the same, although the characters in the meanwhile, as we have seen, have attained a much greater sharpness. But, besides this, we shall be able often to make use of the stand-point arrived at in the above explanations in our further statements, in order to attach our own observations, without being constantly obliged to make long digressions.

[To be continued.]

XIII._On the Microxylobius Westwoodii, Chevr., from St. Helena. By T. Vernon Wollaston, M.A., F.L.S.

Having lately had an opportunity, through the kindness of W. W. Saunders, Esq., of examining the type of the little Curculionideous Microxylobius Westwoodii, from St. Helena, which was described in the first volume of the Entomological Society's Transactions, and which, after the lapse of thirty-six years, still remains unique in his collection, I have thought that it would be worth while to draw out an accurate diagnosis of it, in order to call attention to the exact characters in which it recedes from the other members of the genus (twelve in number) which have hitherto been brought to light. And this seems to be the more desirable, since the few words of M. Chevrolat which take the place of a description are quite insufficient for even its approximate identification. Judging: solely from the excellent figure of it which was supplied by Prof. Westwood, I had imagined that it might perhaps prove to be identical with the species which I enunciated, in 1869, under the name of vestitus; but I now perceive that it is not only totally distinct from that insect, but equally so (as may be gathered from the subjoined remarks) from every other Microxylobius which has come under my notice.

* Der Organismus der Infusionsthiere, ii. p. 168. 


\section{Microxylobius Westwoodii.}

$M$. angusto-elongatus, ovato-cylindricus, obscure subnigro-æneus (et etiam obsoletissime subvirescens), alutaceus, subopacus, calvus; capite rostroque minute et leviter sed argute punctulatis, hoc breviusculo sed lineari et supra subgibboso ; prothorace angusto, cylindrico-subovato, punctulis minutissimis parce et leviter irrorato ; elytris subcylindricis sed pone medium paulo latioribus, confuse transversim rugatis (fere quasi subrimosis) sed haud sculpturatis (i. e. vix striatis et vix punctatis), sutura antice subearinatis ; antennis pedibusque piceo-nigris, illis basi rufo-ferrugineis.

Long. corp. lin. $1 \frac{1}{4}$.

Microxylobius Westrooodii, Chevr., loc. cit. 98 (1836).

$\longrightarrow$ - Woll., ibid. v. (n. s.) 381 (1861).

_— I Id., Ann. Nat. Hist. ser. 4. vol. iv. p. 403 (1869).

Obs. Species inter reliquas distinctissima; differt corpore angustiore et multo magis cylindrico, ubique alutaceo, subopaco, calvo, prothorace minutissime tantum parceque punctulato, elytris transversim substriguloso-rugatis sed longitudinaliter vix sculpturatis, sutura antice acutiusculo, subcariniformi.

Judging from the type before me, this little Microxylobius is as small as even the $M$. vestitus, being only a line and a quarter in length. It is, however, relatively narrower and much more cylindrical than that species (indeed more so than any of the Microxylobii which have hitherto been detected); and it is likewise darker in hue, and perfectly free from even a trace of pubescence. Its rostrum is a little wider than that of the $M$. vestitus, and its tibiæ are rather more curved, and the punctation of its head and prothorax (the latter of which is comparatively unexpanded behind the middle) is even more delicate still; and it is further remarkable for its elytra (which have their suture slightly raised, or somewhat keelshaped, in front) being transversely marked with remote, obscure scratches, or irregular strigæ, but almost devoid of longitudinal sculpture; and its entire surface is coarsely alutaceous, and therefore but very faintly shining.

Before closing this short paper, I may just state that Mr. G. R. Crotch informs me that he possesses two examples of the Cydonia vicina, Muls. (a Coccinellid which is widely spread over the African continent, and which we captured abundantly in the Cape-Verde archipelago), from St. Helena, received by him in company with the $C$. lunata, which is so universal in the island. This, therefore, will add one more species to the St.-Helena catalogue, augmenting the entire 
number to 96 ; and I would desire, consequently, to record it as follows :-

\section{Cydonia vicina.}

Cheilomenes vicina, Dej., Cat. 459 (1837).

- circumflexa (Klug), Id., ibid. (1837).

Cydonia vicina, Muls., Sécurip. 440 (1851).

_ —, Woll., Col. Hesp. 155 (1867).

$H a b$. Sanctam Helenam, teste cl. G. R. Crotch.

I have likewise a note from $\mathrm{Mr}$. Crotch to the effect that the Spharidium dytiscoides of Fabricius is still preserved in the Banksian collection, and that a friend of his who has recently examined it reports it to be totally distinct from the Dactylosternum abdominale, being, in point of fact (as, indeed, I had ventured to think probable), a true Cyclonotum, and one which occurs also at the Cape of Good Hope.

XIV.-On the Anatomy of the Nervous System of Diphyes, affording presumptive evidence of the existence of a similar System in the other forms of Oceanic Hydrozoa. By JoHn Denis Macdonald, M.D., F.R.S., Staff-Surgeon of H.M.S. 'Lord Warden.' *

While cruising off the coast of Portugal, a few hauls of the towing-net brought up many specimens of a species of Diphyes which I have not determined, as the suitable books were not at hand; this, however, may be readily done by referring to the figure accompanying this paper. I very carefully examined several of these animals (or, I am rather tempted to say, animal forms) in relation to the received views of the structure and organization of the group to which they belong. In some instances the two nectocalyces were nearly intact, while in others they were separated, which is more usually the case. This latter remark is also quite true of the parts of numerous other oceanic Hydrozoa, which were quite problematical to most students of zoology until Professor Huxley elucidated their structure by independent research, which enabled him also to render the results obtained by others more intelligible.

In the present species the proximal nectocalyx is about twice as large as the distal one, sharp-pointed, three-sided, and much laterally compressed at the free extremity, but distinctly quadrilateral at the base, where two angular pro-

* Communicated by the Director-General of the Medical Department of the Navy. 


\section{$2 \mathrm{BHL}$ Biodiversity Heritage Library}

Wollaston, Thomas Vernon. 1872. "XIII.—On the Microxylobius Westwoodii, Chevr., from St. Helena." The Annals and magazine of natural history; zoology, botany, and geology 9, 112-114. https://doi.org/10.1080/00222937208696549.

View This Item Online: $\underline{\text { https://www.biodiversitylibrary.org/item/54555 }}$

DOI: https://doi.org/10.1080/00222937208696549

Permalink: https://www.biodiversitylibrary.org/partpdf/53770

\section{Holding Institution}

Smithsonian Libraries

\section{Sponsored by}

Smithsonian

\section{Copyright \& Reuse}

Copyright Status: Public domain. The BHL considers that this work is no longer under copyright protection.

This document was created from content at the Biodiversity Heritage Library, the world's largest open access digital library for biodiversity literature and archives. Visit BHL at https://www.biodiversitylibrary.org. 